зб. наук. праць. - Київ : Вид-во НПУ імені М. П. Драгоманова, 2019. Вип. 69. С. 78-83.

2. Ілляхова М. В. Розвиток креативної компетентності педагогічних працівників у системі післядипломної освіти : спецкурс. НАПН України, ДВНЗ «Унт менедж. освіти». К., 2015. 68 с.

3. Ковалевська Н. Професійна підготовка студентів факультетів дошкільної педагогіки до роботи у сім'ях: автореф. дис. ... канд. пед. наук : 13.00.04. Київ, 2007. 20 с.

\title{
DOI https://doi.org/10.30525/978-9934-26-041-4-10
}

\section{ПІЛОТНЕ ДОСЛІДЖЕННЯ ОСОБЛИВОСТЕЙ ПІЗНАВАЛЬНИХ ПСИХІЧНИХ ПРОЦЕСІВ І ПРОГНОСТИЧНИХ ЗДІБНОСТЕЙ ДІТЕЙ МОЛОДШОГО ШКІЛЬНОГО ВІКУ}

\author{
Горелова В. О. \\ аспірант кафедри загальної та диференціальної психології \\ Південноукраӥнський національний педагогічний університет \\ імені К. Д. Ушинського \\ м. Одеса, Україна
}

Молодший шкільний вік $є$ важливим етапом в розвитку особистості, адже саме в цей період відбувається активний психічний та особистісний розвиток дитини, що зумовлюється особливістю соціальної ситуації розвитку - навчанням у початковій школі. Результатом провідної навчальної діяльності $\epsilon$ стрімкий розвиток пізнавальних психічних процесів, інтелекту, здібностей, засвоєння знань, оволодіння новими уміннями та навичками, основою яких $\epsilon$ пізнавальний інтерес та нова соціальна позиція. Під впливом навчання у школі всі психічні процеси починають перебудовуватися та адаптуватися до нових умов. Традиційне навчання у школі стимулює активний розвиток уваги, пам'яті, мислення, уяви, мовлення безпосередньо через пізнання оточуючого світу та формує узагальнені способи розумових дій. Тому окремі вміння, яких діти набули до початку навчання в школі, $є$ недостатніми для адаптації у світі 3 великою кількістю діяльностей та можливостей. Отже, і виникає необхідність виокремити спільні для всіх умінь характеристики - 
знання, які можуть бути перенесені на інші види діяльностей. Загальну схему співвідношення між уміннями і знаннями дав Г. С. Костюк «узагальнені знання стають компонентами здібностей, входять до складу умінь людини діяти, оперувати ними при розв'язанні нових задач» [1, с. 318$]$.

3 точки зору розвитку здібностей, оволодіння узагальненими способами розумових дій через рефлексію предметних дій і операцій $\epsilon$ основою для формування загальних здібностей. Те, що це збігається із провідною роллю учбової діяльності, мабуть не є випадковістю, а скоріше - закономірністю, пов'язаною 3 культурно-історичною ситуацією розвитку суспільства. Учіння забезпечує як розвиток пізнавальних процесів, так і мотивації, і вольової регуляції, які входять до структури здібностей [2, с. 145].

Оскільки у молодшому шкільному віці стрімко розвиваються здібності, то не буде винятком і розвиток прогностичних здібностей, який відбувається на різних рівнях пізнавальної діяльності. На етапі молодшого шкільного віку прогностична здатність досягає статусу регулюючої, когнітивної та комунікативної функцій. Тобто, завдяки вмінню прогнозувати молодший школяр може контролювати навчальну діяльність, а психічні процеси за таких умов набувають якісних змін, які пов'язані 3 функцією свідомості. Аналізуючи та співставляючи різні ситуації, які виникають при взаємодії 3 однолітками та дорослими, діти здатні передбачати вчинки i дії оточуючих [4].

Л. О. Регуш у своїх дослідженнях розкриває ознаки, які визначають сутність прогнозування як психічної діяльності. По-перше, прогнозування розуміється як пізнавальна діяльність людини. Подруге, прогнозування дає можливість отримати знання про майбутнє за певних умов. По-третє, прогнозування визначається як пізнавальна прогностична діяльність, результат якої має свою специфіку: відображення майбутнього з урахуванням імовірності його настання та різної часової перспективи [4, с. 17].

Спираючись на першу ознаку, яку виділили Л. О. Регуш, є підстави вважати, що розвиток серії пізнавальних процесів буде сприяти розвитку прогностичних здібностей.

Л. О. Регуш, Н. Л. Сомова, О.К. Черанєва вивчали якості пізнавальних психічних процесів, які забезпечують успіх прогнозування та простежили зв'язок між здатністю до прогнозування та іiі проявом в різних пізнавальних процесах. У нашому дослідженні ми продовжимо досліджувати це явище та його особливості у дітей молодшого шкільного віку. 
Для того, щоб побачити зв'язок прогностичних здібностей 3 пізнавальними психічними процесами, а також для підготовки до основного етапу емпіричного дослідження (перевірки діагностичної спроможності комплексу обраних методик, часу роботи з кожною методикою, зрозумілості завдань та інше), нами було проведено первинне визначення рівня розвитку пізнавальної діяльності дітей молодшого шкільного віку за допомогою психодіагностичного комплексу (ПДК), розробленого та апробованого доктором психологічних наук Л. І. Переслені, доктором медичних наук О. М. Мастюковою та кандидатом психологічних наук Л. Ф. Чупровим. ПДК складається 3 трьох методик: методика дослідження особливостей прогностичної діяльності («Вгадайка»), створена Л.І.Переслені та В. Л. Подобєдом; методика діагностики рівня розвитку словеснологічного мислення, сконструйована Е. Ф. Замбацявичене на основі словесних субтестів Р. Амтхауера. Методика суттєво модифікована Л. І. Переслені та О. М. Мастюковою; кольорові прогресивні матриці Дж. Равена (дитячий варіант) в модифікації Т. В. Розанової.

У пілотному дослідженні приймали участь 14 дітей, серед них: 7 дітей віком від 8 до 9 років: 3 дитини -8 років і 4 дитини -9 років, учні загальноосвітньої школи міста Одеси.

За методикою «Вгадайка» були отримані такі результати: всі діти продемонстрували високий рівень сформованості процесу прогнозування з використанням раціональних стратегій передбачення та були віднесені до II а типу прогностичної діяльності, оскільки у кожної дитини були наявні помилки відволікання. Всі учні мають високий рівень відображення та відтворення, що забезпечує нормальне функціонування довготривалої пам'яті. Переключення та розподіл уваги у всіх дітей знаходиться в межах норми. Стійкість уваги у 4 дітей в межах норми, а 2 дітей 8-річного віку та 1 дитина 9-річного віку мають недостатній рівень розвитку стійкості уваги.

За методикою «Словесні субтести», яка досліджує розвиток словесно-логічного мислення, 2 дітей показали високий рівень успішності рішення субтестів з результатами 95\% та 90\%; 5 дітей достатній рівень успішності рішення субтестів з результатами 78,75\% (2 дітей), 77,5\% (1 дитина), 68,75\% (1 дитина), 65\% (1 дитина). Найбільша кількість помилок у всіх дітей простежується у третьому субтесту, який направлений на виявлення рівня сформованості логічної дії «умовивід по аналогії». При виконанні цього субтесту діти зазнавали труднощів через те, що не завжди могли встановити логічний зв'язок і відношення між предметами. 
За методикою «Кольорові прогресивні матриці Дж. Равена» (дитячий варіант), яка направлена на дослідження рівня розвитку зорової перцепції, наочно-дійового та наочно-образного мислення, 5 дітей показали високий рівень успішності рішення матричних задач, 2 дітей достатній рівень. Найбільш складними для дітей виявилися завдання, які передбачали рішення простих і складних наочних аналогій.

Проведена робота показала, що обраний комплекс методик психометрично валідний до вивчення прогностичних здібностей та пізнавальних психічних процесів у дітей молодшого шкільного віку. Отримані пілотні результати показали спроможність обраних методик оцінювати особливості розвитку пізнавальних психічних процесів та прогностичних здібностей дітей молодшого шкільного віку. Подальшу роботу вбачаємо у збільшені кількості випробуваних дітей та розробці корекційно-розвивальної програми, яка допоможе розвивати прогностичні здібності та тренувати пізнавальні психічні процеси у дітей молодшого шкільного віку.

\section{Література:}

1. Костюк Г. С. Навчально-виховний процес і психічний розвиток особистості - К.: Рад. шк., 1989. - 608 с.

2. Музика О. Л. Розвиток здібностей та обдарованості в процесі вікового розвитку особистості. Актуальні проблеми психології: Проблеми психології творчості та обдарованості. Збірник наукових праць Інституту психології ім. Г. С. Костюка АПН України. Житомир: Вид-во ЖДУ ім.І.Франка, 2007. Т.12, вип. 2. С. 142-148.

3. Переслени Л. И. Психодиагностический комплекс методик для определения уровня развития познавательной деятельности: дошкольный и младший школьный возраст. - М.: Айрис-пресс, 2006. -64 c.

4. Регуш Л. А. Психология прогнозирования. Успехи в познании будущего. - СПб: Речь, 2003. - 352 с.

5. Сергєєнкова О. П., Столярчук О. А., Коханова О. П., Пасєка О. В. Вікова психологія. Навч. посіб. - К.: Центр учбової літератури, 2012. - 376 с. 